\title{
The Relationship of Sleep Hygiene With Quality of Sleep in Adolescents
}

\author{
Dwi Happy Anggia Sari ${ }^{1 *}$ and Nindy Annisa ${ }^{2}$
}

\author{
1,2 Faculty of Sports Sciences, Universitas Negeri Padang, West Sumatra, Indonesia \\ *Corresponding author. Email: dwi.happyanggia@gmail.com
}

\begin{abstract}
A Young person is somebody who is $12-18$ years of age. Somebody said to be a young person when it has created sexual development and settling his way of life as an individual isolated from the family, self-planning to confront tasks, decide the future, and wind up arriving at develop age as indicated by law. Rest is a fundamental need that is required by everybody. Rest for youngsters is helpful for keeping up the state of the body in the move, including to accomplish ideal learning results. Somebody who encounters rest cycle issues can influence wellbeing so it will influence rest quality. Helpless rest quality is typically brought about by awful conduct or movement propensities before bed. One endeavor to accomplish great rest quality by improving conduct rest cleanliness. Rest cleanliness is a propensity that can influence rest. This examination plans to decide the relationship of rest cleanliness with the nature of rest in youths at SMK in Padang. This exploration is systematic examination with cross sectional methodology and utilizing the Relative Delineated Irregular Testing Technique.Data is gathered by utilizing a poll. This examination directed in Spring - July 2017. Tests numbered 68 individuals, upwards of 30 individuals had helpless rest cleanliness $(44.1 \%)$, great rest cleanliness 38 individuals $(55.9 \%)$. Upwards of 34 individuals (half) had helpless rest quality and 34 individuals (half) had great rest quality. It is required in youngsters to improve their propensities prior to hitting the sack improve the nature of rest to be acceptable.
\end{abstract}

Keywords: Adolescents, sleep hygiene, quality of sleep

\section{INTRODUCTION}

A Teenager is someone who is $12-18$ years old. Someone said to be a teenager when it has developed sexual maturity and stabilizing his identity as an individual separated from the family, self-preparation to face assignments, determine the future, and end up reaching mature age according to law. Changes that occur in adolescence will affect the increase in activity. Increased activity in adolescent must be balanced with a healthy intake of nutrients, rest, and adequate sleep (Colrain, 2011).

Sleep is an essential need that is required by everybody.In sleep conditions, the body will restore stamina to be in optimal condition. Sleep can be eliminate fatigue, sadness, and bad feelings (Susilo, 2011). National Sleep Foundation (2014) said that sleep duration for normally teenager is 8,5-9,25 hours per day.

Insufficient of sleep for teens will make it difficult to concentrate while studying and sleepy. Adolescents who lack sleep will be experience excessive sleep in the morning, which will automatically have an adverse effect to learning activities and social relationships whit other teenagers
(Mindell, 2010). The physical environment for sleep will be affects to ability fall a sleep. Sound also affects one's sleep, if you usually sleep in peace but you must hear your friend snoring, so you can't interfere with sleep (Potter \& Perry, 2005).

Teenagers who always have irregular hours of sleep, because they often stay up late and do not have a priority of sleep to restore their body condition. Sleep in adolescents becomes irregular due to environmental health status and psychological stress (Asmadi, 2008). For example, they anxiety about their personal problems or situations who can disturb their sleep. Continued stress can make poor for their sleep habits (Potter \& Perry, 2005). Data of The National Sleep Foundation (2014) said, in America there are at least 40 million people suffering from sleep disorder. The most data occurred in adolescents, namely 69\%. Epidemiological studies related to the prevalence of sleep disorder in adolescents have not been done in Indonesia. A study conducted by Awwal (2015) found that adolescents age 12-15 years experienced a prevalence of sleep disorders of $81,1 \%$. 
Quality of sleep is where rest that is lived by an individual produces newness and wellness when stirred. Quality of Sleep is an individual's fulfillment with rest so the individual doesn't show sentiments of weariness, uneasiness, dormancy and indifference, obscurity around the eyes, swollen eyelids, red conjunctiva, disturbed eyes, divided consideration, cerebral pains and incessant yawning or sluggishness (Budiawan, et, al, 2016). Poor sleep quality is usually caused by bad behavior or activity habits before sleep. One effort to achieve good sleep quality is by improving sleep hygiene behavior (Nishinose, et, al, 2012).

The application of sleep hygiene is divided into 3 activities, namely behavior, environment, and activitier before going to sleep. These behaviors can determine walking and sleeping time by avoiding short sleep, avoiding alcohol 4-6 hours before go to bed, avoiding caffeine consumption 4-6 hours before go to slee, and avoiding heavy food. The application of the environments is done by using a confortable bed, conditioning the temperature and ventilation and avoiding noise and bright light (Nishinoue, et al, 2012).

Research by Lumantiw et al (2016), 52,2 \% of adolencents who experience very poor sleep quality are affected by the presence of various electronic media such as watching tv, cellphones, laptops or computers.another habit that teenagers do before going to sleep is smoking and consuming caffeine. Caffeine consumption make it difficult for teenagers to start sleeping. Incorrect application of sleep hygiene will actually cause someone to experience insomnia (Nishinoue, et al, 2012).

\section{METHODS}

The sort of exploration is analytic research with cross sectional methodology. The populace in this examination was 213 individuals with a sampel of 68 people. The testing procedure is proportional stratified with random sampling. In the univariate analysis of the variable sleep hygiene, an analysis of the measurement results using means. In the bovariate analysis ChiSquare test was performed.

\section{RESULT AND DISCUSSION}

A. Result

1. Sleep Hygiene

Table 1. Frequency distribution of respondents base on sleep

\begin{tabular}{|c|c|c|c|}
\hline Number & Sleep Hygiene & $\boldsymbol{f}$ & $\%$ \\
\hline 1 & Poor & 30 & 44,1 \\
\hline 2 & Good & 38 & 55,9 \\
\hline & Total & $\mathbf{6 8}$ & $\mathbf{1 0 0 \%}$ \\
\hline
\end{tabular}

\section{Quality of sleep}

Table 2. Frequency distribution of respondents based on sleep quality

\begin{tabular}{|c|c|c|c|}
\hline Number & Quality of sleep & $\boldsymbol{f}$ & $\%$ \\
\hline 1 & Poor & 34 & 50,0 \\
\hline 2 & Good & 34 & 50,0 \\
\hline & Total & $\mathbf{6 8}$ & $\mathbf{1 0 0 \%}$ \\
\hline
\end{tabular}

3. Relationship of sleep hygiene with quality of sleep

Table 2. Frequency distribution of respondents based on sleep quality

\begin{tabular}{|c|c|c|c|}
\hline \multicolumn{4}{|c|}{ Quality of sleep } \\
\hline Sleep hygiene & $\begin{array}{c}\text { Poor } \\
\%\end{array}$ & Good \% & Total \% \\
\hline Poor & 86,7 & 13,3 & 100 \\
\hline Good & 21,1 & 78,9 & 100 \\
\hline Total & 88,2 & 50,0 & 100 \\
\hline
\end{tabular}

In light of table 3 above it very well may be seen that from 68 respondents, namely 30 adolescents have sleep hygiene find that the percentage of poor sleep quality is higher than good quality of sleep. While of 38 adolescents who have good sleep hygiene find the percentage of good sleep quality is higher than poor quality of sleep.

From the statistical tests there is a connection between sleep hygiene and quality of sleep in adolescents ( $\mathrm{p}$ value $=0,000$ )

\section{B. Discussion}

\section{Sleep Hygine}

Univariate test results showed that as many as $55,9 \%$ of adolescents have good sleep hygiene while $44,1 \%$ of adolescents have poor sleep hygiene. The measurement of sleep hygiene uses an adolescent sleep hygiene questionnaire that was modified by researcher.

The result of research conducted by Febriyati (2015) about the relationship of sleep hygiene to insomnia in adolescents in the Harjosari Village in which the result obtained are that the behaviorof sleep hygiene in adolescent most categories are not good that is as much as 70,0\%. This shows that the sleep hygiene behavior in adolescents is not good. Sleep hygiene is a behavioral component for insomnia that refers to things that can be done to facilitate insomnia sufferers to be able to sleep well (Teofilo, 2007). The results of another study conducter by Rahmah (2014) showed that the elderly had poor sleep hygiene (75\%).

Sleep hygiene is a propensity that can influence sleep, sleep cleanliness improvement is a straightforward however compelling approach to improve quality of sleep (Puspitosari, 2008). The Great 
sleep hygiene conduct can help someone in having a good quality sleep. The habit of someone who sleeps during the day more than 1 hour indicates that someone has poor sleep hygiene (Amir, 2007).

The application of sleep hygiene is divided into 3 activities, namely behavior, environment, and activities before going to sleep. Some behaviors are avoided and some are done before going to sleep. Behavior determines wake time and sleep time by avoiding sleep for a while, avoiding consuming caffeine 4-6 hours before going to bed, avoiding alcohol 4-6 hours before going to sleep, and avoiding heavy food. Behavior that can be done such as doing light exercise and consuming warm milk.

The habit of drinking coffee 4-6 hours before bedtime can disrupt sleep patterns because caffeine blocks adenosine receptors. Adenosine is a neurotransmitter whose effect is to reduce the activity of cells, especially nerve cells. Therefore, if the adenosine receptor binds to caffeine, the opposite effect is produced, thus explaining the effects of caffeine stimulation (Allsbrook, 2008).

Savoring liquor 4-6 hours before sleep time causes despondency or accentuation on the useful action of the focal sensory system. Decreased functional activity of the central nervous system results in decreased number of organ functions, such as the center of consciousness, pain, pulse, and breathing and disrupt sleep patterns. Smoking before going to sleep causes insomnia because nicotine has the effect of stimulating serotoninergic neurons in the brain so that the levels increase compared to normal, which increases the awake phase and difficulty sleeping. Under normal circumstances, many serotoninergic neurons are present in a state of wakefulness and then decrease in the NREM tidus stage and eventually the levels become less in the REM sleep stage (Suastari, 2014).

The application of the environment is done by using a comfortable bed, conditioning the temperature, ventilation and avoiding noise and bright light (Nishinoue, et al, 2012). Environmental factors play a role as a supporter or inhibitor of the sleep process. Some people like the dark light and some others prefer the dim light and bright light during sleep. On one side, there are people who are accustomed to sleeping with dark lighting or minimizing sound, such as by adjusting the television so it is calmer (Kozier, et al, 2011).

\section{Quality of sleep}

Sleep of quality Univariate test results indicate that adolescents have the same quality of sleep that is as much as $50 \%$ of poor sleep quality and $50 \%$ have good sleep quality in youths at SMK in Padang. Sleep quality is divided into good sleep quality and helpless sleep quality. Helpless sleep quality is a type of insmonia. The consequences of this study are in accordance with research directed by Febriyati (2015) about the relationship of sleep hygiene to a sleeping disorder in young people at Harjosari Village where the results are that sleep hygiene behavior in adolescents is mostly in a bad category with 63 teenagers (70.0\%). Lumantow, et al (2016) about the relationship of sleep quality with blood pressure in adolescents in the village of Tombasan found $52.2 \%$ of adolescents who experienced very poor sleep quality influenced by the presence of various electronic media such as watching tv, cellphones, laptops, or computers. The behavior of the use of gadgets at night can affect the behavior before going to sleep, causing poor sleep quality (Pramanik, et al, 2012). Changes in sleep designs in young people is a change in biological clock or called a circadian mood. Toward the start of pubescence, the period of rest turns out to be late. Time to sleep so late and get up late in the morning. Teenagers often wake up at night and become more difficult to sleep. Nighttime sleep and wake up based on school schedules and social life will affect the reduction of sleep time in adolescents (Sofyani, 2011). Sleep quality is somebody's fulfillment with sleep so the individual doesn't show sentiments of exhaustion, uneasiness, torpidity, darkness around the eyes, swollen eyelids, red conjunctiva, absence of center consideration, migraines and regular yawning or sleepiness (Budiawan, et al, 2016). Sleep quality comprises of seven segments in particular, emotional sleep quality, sleep dormancy, sleep span, sleep proficiency, sleep unsettling influence, utilization of dozing pills and exercises during the day. Good sleep quality is when someone feels satisfied with his sleep and feels refreshed when he wakes up sleep, whereas poor sleep quality if someone feels tired, anxious, lethargic and disrupted activity during the day (Budiawan, et al, 2016). Factors affecting sleep quality are illness, the environment, fatigue, emotional stress, medication, motivation and smoking (Hidayat, 2009). Meanwhile, according to Gunanthi (2016) age and sex factors also affect one's sleep quality. The increasing age of sleep patterns will change so that it will affect one's sleep quality. Changing sleep patterns are caused by busyness and social demands that can have an impact on sleep quality.

3. Relationship of sleep hygiene with quality of sleep

Of 68 respondents, namely 30 adolescents who had poor sleep hygiene had $86.7 \%$ of helpless quality of sleep and $13.3 \%$ have great quality of sleep While from 
38 adolescents who have good sleep hygiene, $21.1 \%$ get poor sleep quality and $78.9 \%$ get good sleep quality. Chi-Square statistical test outcomes got Pvalue $=0,000$ (Pvalue <0.005) then concluded Ho was dismissed, implying that there is a connection between sleep hygiene with quality of sleep in teenagers at SMK in Padang at 2017.

The consequences of this study are in accordance with research directed by Rahmah (2014) about the relationship of sleep hygiene with quality of sleep in the elderly with 65 elderly people, as many as 42 people $(75 \%)$ have poor sleep hygiene behavior. The consequences of this study are in accordance with research directed by Mastin, et al, (2006) showing a positive correlation between the Sleep Hygiene Index (SHI) score and the Pittsburgh Sleep Quality Index (PSQI) score with a value is 0.481 , which is moderate correlation strength. Other studies by Mindell et al. (2009) have concluded that great sleep hygiene conduct is related with acceptable sleep.

Sleep hygiene is an important factor in sleep quality in adolescents (Tan, 2012). Sleep hygiene is carried out to establish a regular sleep schedule and consistent sleep routines as well as conditioning a good sleep environment with a view to harmonizing sleep and wake cycles with other body cycles such as body temperature, metabolism and hormonal schedules that form synchronization of circadian rhythms to achieve a state of homeostasis threatened by the stress of hospitalization (Tan, 2012).

Sleep hygiene is one of the exercises or habits that can affect sleep. Improved sleep hygiene is one of the simple but effective ways to improve sleep quality (Puspitosari, 2008). Great sleep hygiene behavior can forestall the advancement of sleep issues and issues. This implies that great sleep hygiene conduct can help somebody in having great quality of sleep. Sleep unsettling influence during the day demonstrates that somebody has helpless sleep hygiene (Amir, 2007).

Great sleep hygiene conduct should be improved to improve quality of sleep. The application of inadequate sleep hygiene has a significant relationship with poor sleep quality (Suen, et al, 2010). Sleep hygiene behaviors such as the use of beds for activities that are not appropriate to sleep such as watching television or eating will reduce the quality of sleep. Activities other than sleep carried out on the bed will affect the work of the brain so that it always feels that the bed is not related to sleep activity. This increases the difficulty of starting sleep (Sayeti \& Hendrati, 2015). This research has demonstrated that sleep hygiene conduct impacts quality of sleep so it tends to be utilized as a non-pharmacological way to deal with make sleep propensities better (Malone, 2011).

\section{CONCLUSION}

From the result obtained in the study of the relationship of sleep hygiene with sleep quality in adolescents, researchers can draw conclusions The distribution of sleep hygiene frequency in adolescents is more than half good sleep hygiene, the frequency distribution of sleep quality in adolescents is the same between good sleep quality and poor sleep quality, then there is a relationship between sleep hygiene with sleep quality in adolencents.

\section{REFERENCES}

[1] Ahsan, dkk. Pengaruh Sleep Hygiene Terhadap Gangguan Tidur pada Anak Usia Sekolah yang Menjalani Hospitalisasi. Diakses dari: http://ejournal.umm.ac.id/index.php/keperawatan/ar ticle/viewFile/2846/3552 diakses tanggal 15 Maret $\underline{2017}$

[2] Ambarawati, F.R. 2014. Konsep Kebutuhuhan Dasar Manusia. Yogyakarta : Parama Ilmu

[3] Asmadi. 2008. Konsep dan Aplikasi Kebutuhan Dasar Klien. Jakarta : Salemba Medika

[4] Atoilah, E. M \& Kusnadi, E. 2013. Askep pada Klien dengan Gangguan Kebutuhan Dasar Manusia. Garut : In Media

[5] Awwal, H. 2015. Prevalensi Gangguan Tidur pada Remaja Usia 12-15 tahun : Studi pada Siswa SMP N 5 Semarang. Media Medika Muda 4(4) : 873-880

[6] Budiawan, dkk, 2016. Pengaruh Monoton, Kualitas Tidur, Psikofisiologi, Distraksi, dan Kelelahan Kerja terhadap Tingkat Kewaspadaan. Vol,XI,hlm 6, diakses dari http://www.undip.ac.id tanggal 23 Maret 2017

[7] Efendi, F. 2013. Sleep Hygiene Behavior among Balinese Adolescent Diaksesdari:www.sciedu.ca/journal/indx.php/jnep/a rticle/download/321/7/2169 tanggal 2 April 2017

[8] Febriyati, T. 2015. Hubungan Sleep Hygiene terhadap Insomnia pada Remaja di Kelurahan Harjosari Kecematan Bawen Kabupaten Semarang.

[9] Hidayat, A. Aziz Alimul. 2009. Pengantar Kebutuhan Dasar Manusia : Aplikasi Konsep dan Proses Keperawatan. Jakarta : Salemba Medika

[10] King, Laura A. 2013. Psikologi Umum : Sebuah Pandangan Apresiatif. Jakarta : Salemba Humanika 